\title{
Availability and use of audiovisual resources in two selected tertiary institutions of Nigeria
}

\author{
${ }^{1}$ Lucky U. Oghenetega (CLN), ${ }^{2}$ Amugen, Sarah (CLN) \\ ${ }^{1}$ Library and Information Science, Madonna University Okija,Anambra State E- mail:tega4realO6gmail.com \\ ${ }^{2}$ Head, Catalogue and Classification Department Federal Polytechnic Library Ede, Osun State.
}

\begin{abstract}
This aim of this study was on availability and use of audiovisual resources in two selected tertiary institutions of Nigeria. The study discussed meaning of audiovisual resources, types of audiovisual available in the two institutions used. Survey method was adopted and instruments were observation checklist and oral interview. The population of the study are all registered students in the library. Findings showed that students are not allowed to use audiovisual resources most of the times and management of the both institutions have not done much in audiovisual department. Based on the findings the researchers proffer some solutions to both institutions and others in Nigeria.
\end{abstract}

Keywords: Audiovisual, library resources, non-print, use and availability of audiovisual.

\section{Introduction}

The terms non-print, non-book and audiovisual materials /resources are used interchangeably in librarianship. In lines with this statement Nathan (2010) stated that audiovisual materials are usually described as " non-print documents", in the sense also been called "non-boook" or "special formats" and sometimes require equipment to use. It is for this reason that audiovisual materials are sometimes classified into two groups - "projected materials" and non- projected materials". Audiovisual materials include sound recordings, film and video, graphic materials, three dimensional objects, maps, and microforms etc. An ever-increasing amount of information - covering educational and recreational interests as well as information needs - is being produced in a wide range of audiovisual and electronic formats ( CDs \&DVD). Access to these materials should be as open and as free as access to print-based materials. Audiovisual media are part of our cultural heritage, carrying a huge amount of information that needs to be preserved for future use. The rich variety of media expressions in society should be reflected in the services offered to users by the libraries. (Ekaette, 2004).

All over the world, nations are increasingly becoming aware of the role played by audiovisual materials or resources. The value of audiovisual materials was perhaps clearly stated by the International Federation of Library Associations and institutions (2003) cited in Nathan (2010) asserted that:

In no circumstances should audiovisual (AV) materials be regarded as additional luxury materials but rather they should be considered as necessary components in a fully integrated library service... In developing countries the provision of AV materials and their associated equipment might be regarded as of greater importance than the printed word because the level of literacy is such that oral and visual communication is essential for the purposes of communication.

Despite the fact that audiovisual or non- print materials play a vital role in the preservation of cultural heritage, they are very often neglected. According to Madu (2000) opined that Librarians, as information providers, should be concerned with the provision of information in the formats most suited to the differing needs of various types of user, each of which must be clearly differentiated. While Obanya (2002) said that a library exists to serve its community and consequently the needs of all members of that community must be accommodated - the old and the young, the able and the disabled, the gifted and the backward members of the society. Non-print materials can reach out to sections of the public for whom the traditional print-based materials have little impact, e.g. to those who are reluctant to use the printed word, and to those with visual and other handicaps.

Obanya (2002) moved further, in developing countries the provision of non-book materials and their associated equipment might be regarded as of greater importance than the printed word because the level of literacy is such that oral and visual expressions are essential for the purposes of communication. The need for still images, films and sound on the more traditional non-electronic audiovisual carriers still exists alongside the growing possibilities of the Internet. Multimedia and computer based information have contributed to a great explosion of audiovisual materials in libraries. Almost every library user or visitor is a potential user of audiovisual and multimedia materials as well as of print. (Omekwu, 2002). 


\section{Statement of the Problem}

Over world there has been significant development in communication of information in different formats to the society. Information is being packaged and repackaged in print, electronic and non- print formats to people in needs. Nathan, (2010) observed that audiovisual materials play a vital role in the preservation of cultural heritage, they are very neglected). The organization and utilization of non- print materials in many electronic media libraries are the major challenges facing the staff ( Madu and Adeniran,2005).

It is important that library staff realize the potential of the non- print resources in their library and efforts should be made to incorporate them into their collection, get them organized and utilize properly by users. Hence, the question what are the audiovisual resources available and whether undergraduates are allowed to use them tertiary institutions of Nigeria? This is the gap the researchers tried to cover in body of knowledge in Librarianship.

\section{Objectives of the study}

i.To determine the types of Audiovisual resources stocked in library

ii. To find out how audiovisual/ multimedia resources been managed by librarians in institutions.

iii.To identify the problems faced by librarians in organizing and utilizing non- book materials or resources.

\section{Concept of Audiovisual resources in Libraries}

\section{Review of Related Literature}

As earlier explained by Nathan (2010) stated that audiovisual materials are usually described as " nonprint" documents, in the sense also been called "non-book" or "special formats" and sometimes require equipment to use. It is for this reason that audiovisual materials are sometimes classified into two groups "projected materials" and non- projected materials". Audiovisual materials include sound recordings, film and video, graphic materials, three dimensional objects, maps, and microforms etc. According to library glossary online (2010) defined non-print or audiovisual materials, as items in formats other images or words printed on paper. Examples include films, slides, audiotapes, CDs videocassettes, and computer software. Edmondson (2004) proposes wider definition of audiovisual heritage which he suggests ought to include:

$>\quad$ Recorded sound, radio, television, video or other productions comprising moving images and /or recorded sounds, whether or not primarily intended for distribution to the public.

Objects, materials, works and intangibles relating to audiovisual documents, whether seen from technical, industrial, cultural, historical or other viewpoint, this shall include materials relating to film, broadcasting and recording industries, such as literature, scripts, stills, posters, advertising materials, manuscripts, and artefacts such as technical equipment or costumes.

$>\quad$ Concepts such as the perpetuation of obsolescent skills and environments associated with the reproduction and presentation of this media;

$>\quad$ Non-literary or graphical material such as photographs, maps, manuscripts, slides, and other visual works selected in their own right.

As can be seen from the above definition, audiovisual materials encompass different materials. Generally, audiovisual materials may be divided into four major groupings: (i) visual materials (still and motion picture); (ii) audio materials (discs and tape recordings); (iii) objects and manipulative materials (realia and game models); and (iv) machine readable data files ( magnetic tapes, punched cards and aperture cards). (Nathan, 2010 ). According to Agbanu, Ofordile, Okeji, and Ogwu (2010) AV non-print materials are those materials which do not depend solely upon reading to convey meaning. They may present information through the sense of hearing: audio resources, or through the sense of sight: visual resources, or through combination of senses. The term AV material encompasses all those information media that convey their messages without the mediation of the written word. They can be viewed and / or listed to. (Agbanu et al, 2010). Furthermore, Madu and Adeniran (2005) defined Audio- visual materials as a combination of audio and visual materials, which are used in the instructional/learning process to facilitate teaching and learning processes. AV could also mean something that is related to sound and visual or light.

\section{Types of non- book materials in media libraries}

The type of non- print or AV materials found in the electronic media libraries should be such that aid dissemination of information. There are different types of non-print materials in the electronic media libraries as follows:

\section{Media}

This could be defined as any form of device or equipment, which is normally used to transmit information between persons. It could also be instrument used to convey ideas and information. AV media could 
therefore be referred to as materials that are used in the instructional/ learning process. They include: Films, pictures, posters, maps, televisions, slides, charts etc.

\section{Cartoon}

This is a graphic material: It is a pictorial representation of a persons ideas or situation: It is designed to influences public opinion to inform and to entertain. A good cartoon is built on simple idea. Most cartoons explore satire, or mockery, humour and laughter. Certainly the obvious characters of most cartoons can be specified quite easily i.e minimum details, familiar symbols or characters, stereotypes that are quickly recognized and understood.

\section{Microform}

Microform is defined as information either in texture, illustration of tabular form that is stored in reduced sizes on photographic film. It is a generic term indicating any form micro record, whether on film, paper other materials included in this generic name are micro board, microfilm and microfiche etc. example of microform: Microfilm, microfiches, microcards and microprint.

\section{Filmstrips}

In audio-visuals aids, this is series of still pictures on a strip of film, usually single frame- $35 \mathrm{~mm}$, but sometimes 110, super 8 or $16 \mathrm{~mm}$ formals the film strip may silent or provide with an accompanying sound programmes ( tape or record) film strips may be advanced manually as desired or in response to an audible help in the audio source. Some filmstrip equipment can be automatically advanced through inaudible pulse on the tape record.

\section{Slides}

This is individually projectable pieces of $33 \mathrm{~mm}$ film usually mounted in cartboard frames. We can also have audiotape slide which is self of slide accompanied with an audiotape recording. Some signal is available to project the next slide.

\section{Video Tapes}

These are types of non-print materials that require viewing and listening equipment. Videotape recordings are becoming more available to libraries. They are available open real cassette and range from 14 to 21 inches.

According to Adomi (2009) categories AV materials into different types which include: video materials, graphic, audio, microforms, compact disc read only memory, Digital Versatile disk, Divx, transparencies, ran electronic books, electronic journals and internet resources as well as television. The researcher will explain CD-ROM and DVD because of the recent benefits of them among scholars, students and librarians:

\section{Digital Versatile Disk (Dvd)}

Digital versatile Disk was formerly referred to as Digital Video Disk and is identical in appearance to a CD-ROM but with a capacity between $4.7 \mathrm{~Gb}$ and $17 \mathrm{~Gb}$ compared to $556-680 \mathrm{Mb}$ capacity of CD-ROM. DVD comes in two basic forms DVD video and DVD-ROM. The former is seen as the format for consumer electronics which will be used to stimulate the sale rental of Hollywood films at present on lower quality videotape (Adomi, 2006). DVD is seen by many as replacement for CD-ROM in PCs, where the higher capacity will allow increased use of sound and vision, particularly, initially, from the game market but later being applied to training and other multimedia applications, and the distribution of ever-larger software applications Prytherch (2000) as cited in (Adomi, 2006).

\section{Method}

Survey method was adopted. The instruments used were observation checklist and oral interview. The population comprised of all the registered students that were using the library in time of the oral interview at Madonna University Library, Okija and Federal Polytechnic Library Osun State. That is, capture sampling was adopted in the oral interview. This was so, because users are brought together in the library to read, do assignments, and consult digital or traditional library materials and among other reasons. 
Availability and use of audiovisual resources in two selected tertiary institutions of Nigeria

Audiovisual resources available in Madonna University Library, Okija and Federal Polytechnic Library Osun State.

\begin{tabular}{|c|c|}
\hline Madonna University, Library Okija & Federal Polytechnic Library Osun State \\
\hline Television & Television \\
\hline Radio & - \\
\hline LG DVD Player & DVD Player \\
\hline Audio/DVD, CD-Rom & Audio/DVD, CD-Rom \\
\hline Audio cassettes & - \\
\hline Computer & Computer system \\
\hline Projector & - \\
\hline- & Slides \\
\hline Map & - \\
\hline Satellite dish & - \\
\hline Video player & Video player \\
\hline Multimedia Projector & Multimedia Projector \\
\hline- & Video projector, \\
\hline- & Over head projector \\
\hline Wireless microphone receiver & Wireless microphone receiver \\
\hline- & Video camera \\
\hline- & CD writer \\
\hline- & CD duplicator \\
\hline- & Cannon shot digital camera \\
\hline Colour printer & Colour printer \\
\hline Air condition & Air condition \\
\hline Scanner & Scanner \\
\hline- & Micro file \\
\hline- & Filmstrip \\
\hline Grand total & 19 \\
\hline
\end{tabular}

Findings

In Federal Polytechnic Library Osun State during the oral interview, it was found out that studenst always made use of projector, digital camera and video camera more than any other device in the audiovisual unit. The reason why students are not using the rest of the material is that the unit is still under structuring and the materials are not fully available for student use yet. While in Madonna University, Okija it was found out students in Mass Communication and Library and Information Science departments are allowed to use audiovisual resources because of the nature of the departments. And most of these audiovisual are in the departmental library instead of the main library. The reasons behind this are because of accessibility and quick retrieval of information to students on timely. And the audiovisual resources available the Federal Polytechnic are more than Madonna University, Okija.

\section{Conclusion and Recommendations}

From the study showed that audiovisual resources in Library and Information Science as a profession is one of the most information materials utilized by users, staff and other people in the society. Audiovisual or non- print materials play a vital role in the preservation of cultural heritage, but they are very often neglected. Librarians or information providers should be concerned with the provision of information in the formats most suited to the differing needs of various types of user, each of which must be clearly differentiated. Therefore, the study discussed issues on the uses and availability of audiovisual resources but some students are still lack behind and some management of institutions are not helping matter when it comes to creation of audiovisual unit or section. In lines with the findings the following recommendations were made to both institutions and others in Nigeria.

1. The management of Federal Polytechnic Library in Osun State should try to put the audiovisual unit in good shape quickly for students benefit.

2. Management of Madonna University, Okija should try to makes space for audiovisual department in the main library. So that every student will makes use of audiovisual resources effectively.

3. Students should be trained and retrained for how to use audiovisual resources for academic purposes

4. Audiovisual Librarians/ professionals should be employed for the training and also for effective and efficient management. 
5. Management of both institutions should released funds for the purchasing of audiovisual equipments/resources that lack behind.

6. Audiovisual resources should be made available at all times as it with books and digital information resources in the library.

\section{References}

[1]. Adomi, E.E. (2009) Library and information resources . Benin City: Ethiope publishing corporation

[2]. Adomi, E. E. (2006) Collection development and management in context. Warri: Goddick Publisher.

[3]. Agbanu, N.A Ofordile, J. O. Okeji, C.C \& Ogwu, M.F. (2010) Introduction to the use of the library: a fundamental approach . Enugu: Rhyce Kerex.

[4]. Dudley T. (2010)Audio-visual aids benefits and problems of the various types Online publication

[5]. Ekaette, Ufot(2004, April 2) F.G to Introduction information technology in school curriculum. Daily Independent.

[6]. Madu, E.C \& Adeniran (2005) Information technology: uses and preservation of resources in libraries and information centres $2^{\text {nd }}$ edition Ibadan: Evi- Coleman Publications.

[7]. Madu, E.C(2000) The basics of audiovisual librarianship. Ibadan: Evi- Coleman Publications.

[8]. Nathan, M(2010) preservation and management of audiovisual archives in Botswana. African journal of Library, Archives \& information Science Vol 20(20 139-148.

[9]. Non-print media library management. (n.d) Commonwealth Education Media Centre for Asia (CEMCA) workshop handout. New Delhi.

[10]. Obanya, Pai(2002) Some thought on writing at a distances. Oyo Centre for external studies University of Ibandan.

[11]. Omekwu, C.O. (2002) The challenges of information systems in modern libraries. In Madu, E.C. and Dirisu, M.B. (eds) (2002) Information science \& technology for library schools in Africa. Ibadan: Evi- Coleman Publications. 